\title{
Evaluation of valuable agronomic traits of spring triticale in a long-term breeding trial
}

\author{
Irina G. Grebennikova ${ }^{1}$, Anna F. Cheshkova ${ }^{1}$ \\ ${ }^{1}$ Siberian Federal Scientific Center of Agro-BioTechnologies of the Russian Academy of Sciences, Krasnoobsk, Novosibirsk \\ region, Russia
}

\begin{abstract}
The analysis of data of long-term breeding trials of spring hexaploid triticale, used for forage and grains, was carried out using mathematical methods and developed software. The valuable agronomic traits of the ideal variety have been determined. The possibility of purposeful breeding for adaptability to the conditions of the region when creating new high-yielding varieties is shown.
\end{abstract}

Keywords

Spring triticale, plant breeding, valuable agronomic traits, long-term breeding data, computer program.

\section{Introduction}

The main strategy in the breeding of cereals is to create varieties with high productivity potential, which would be realized by at least $70-80 \%$ under actual production conditions. New varieties have the greater value, the more optimally they combine the important biological, economic and technological properties. The beneficial features of the variety can be seen only under certain growing conditions that ensure the realization of its potential productivity. New varieties must combine adaptability to certain agro-climatic zone with all other valuable agronomic traits. When creating a new variety, it is necessary to take into account the agro-climatic zone for which the variety is being created, soil cover, meteorological factors, the spread of diseases and plant pests, and the features of agricultural technology. The breeder also needs to identify critical weather and climatic factors affecting the cereals. All this determines the main direction of crop breeding $[1,2]$.

One of the hopeful crops for Western Siberia is triticale, highly appreciated in many countries including Russia for its versatility and high biological potential. Triticale has a high adaptability to growing conditions, a greater yield on depleted soils compared to wheat, better grain quality than rye and higher protein content in grains. Due to rye genome triticale is immune to many cereal diseases such as powdery mildew, common bunt, loose smut. Its seeds do not require fungicide treatment before sowing which avoids high production costs and preserves the ecological balance of soils. Pests damage triticale less than wheat, due to the presence of biological defense mechanisms [3].

A characteristic feature of triticale is that the earing, flowering and ripening stages occur later and last longer than in wheat. Late earing of triticale is an advantage for forage production

SDM-2021: All-Russian conference, August 24-27, 2021, Novosibirsk, Russia

$\bigoplus$ sibfti.grig@ngs.ru (I. G. Grebennikova)

(c) (1) $\odot 2021$ Copyright for this paper by its authors. Use permitted under Creative Commons License Attribution 4.0 International (CC BY 4.0).

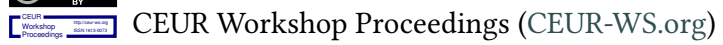


compared to rye. The green biomass yield of forage triticale is 2 times higher than that of wheat. Forage triticale surpasses winter rye in protein, carotenoid and sugar content. Lignification in triticale is slower than in rye, which preserves the feeding quality of the stems after flowering. As a result, green biomass is better eaten by animals and provides higher weight gain. The use of triticale both for fodder and grains in some cases has an advantage over the use of wheat, corn, barley and sorghum. Thanks to these advantages, triticale significantly reduces the cost and diversifies the production of high-quality feed and food grains, and enables rational use of the available soil and climatic resources [4,5]. All these qualities define triticale as a crop of low environmental risk.

Despite a number of beneficial features, spring triticale in Western Siberia is a new and poorly studied crop. Agro-technical methods of triticale cultivation were developed mainly for the European regions of Russia or for foreign countries and therefore are not always acceptable for Western Siberia. Practical experience and scientific research show that foreign varieties have weak local adaptation [6]. An increase in the sowing area of triticale and widespread production of this crop is possible only by creating varieties highly adapted to local agroecological conditions, combining high productivity and high field resistance to various phytopathogens.

The objective of this study is to evaluate morphological and agronomic traits and ecological adaptability of spring triticale used for forage and grain in a long-term breeding trial.

\section{Materials and methods}

Desirable agronomic traits can be identified by analyzing varieties with high adaptive potential, which manifests itself in unfavorable environments, grown for a long time in a specific agroclimatic zone. Adaptation of genotypes to local conditions occurs due to the heterozygosity of triticale and due to the buffering effect of the genetic variety. The advantage of evolutionary selection is that at the end of the trial we have a population enriched with valuable and promising genotypes, which can become material for individual selection. This method helps to determine the desired biotype or model of the ideal variety, towards which the efforts of breeders should be directed.

A field trial was conducted in Novosibirsk region, Russia in 2018-2020 at the fields of SFSCA RAS and SRIPCB (branch of ICG SB RAS). Experiment included three varieties of common wheat and four breeding lines of spring hexaploid triticale (Table 1).

The triticale lines studied in this work are intended for use grains in food and animal feed. When evaluating valuable agronomic traits of spring triticale, comparison was made with wheat varieties of Siberian selection of different ripeness groups. Since at the time of the field trials there were no data on the triticale variety Timur entered in the register of breeding achievements in the West Siberian region in 2020 [7]. Sowing was carried out manually in open ground in four replications, 80 grains in a row with a feeding area of $0.3 \mathrm{~m}^{2}$.

The following traits were registered: plant height, spike length, number of spikelets per spike, ear density, grains weight of an ear, number of grains per spike, weight of 1000 grains, dynamics of plant growth and phenological phases duration. Biological control of plant revealed differences in growth, development and grains formation of spring wheat and triticale, which are influenced by environmental conditions (day length, the spectrum of solar insolation, 
Table 1

Studied triticale lines and wheat varieties.

\begin{tabular}{|c|c|c|c|c|c|}
\hline No & Crop & Variety & $\begin{array}{l}\text { Ripeness } \\
\text { group }\end{array}$ & Origination & Agronomic traits \\
\hline 1 & & $\begin{array}{c}\text { Novosibirskaya } \\
15\end{array}$ & Early & $\begin{array}{l}\text { Russia, } \\
\text { Novosibirsk, } \\
\text { SRIPCB }\end{array}$ & $\begin{array}{l}\text { Resistant to lodging, moder- } \\
\text { ately drought-resistant. Mod- } \\
\text { erately susceptible to common } \\
\text { bunt. Strongly susceptible to } \\
\text { brown and stem rusts, powdery } \\
\text { mildew. }\end{array}$ \\
\hline 2 & $\begin{array}{l}\text { Common } \\
\text { wheat }\end{array}$ & $\begin{array}{c}\text { Novosibirskaya } \\
31\end{array}$ & Mid-early & $\begin{array}{l}\text { Russia, } \\
\text { Novosibirsk, } \\
\text { SRIPCB }\end{array}$ & $\begin{array}{l}\text { Resistant to lodging, moder- } \\
\text { ately drought-resistant. Moder- } \\
\text { ately susceptible to brown rust } \\
\text { and septoria. Strongly suscepti- } \\
\text { ble to loose smut. }\end{array}$ \\
\hline 3 & & Sibirskaya 12 & Mid-late & $\begin{array}{l}\text { Russia, } \\
\text { Novosibirsk, } \\
\text { SRIPCB }\end{array}$ & $\begin{array}{l}\text { Resistant to lodging, drought } \\
\text { tolerant. Moderately suscepti- } \\
\text { ble to septoria. Strongly suscep- } \\
\text { tible to loose smut, brown rust } \\
\text { and powdery mildew. }\end{array}$ \\
\hline 4 & & K-3992 & Early & $\begin{array}{l}\text { Russia, } \\
\text { St. Petersburg, } \\
\text { VIR }\end{array}$ & $\begin{array}{l}\text { Medium-dense ear, with long } \\
\text { awns. Resistant to lodging. Sus- } \\
\text { ceptible to ergot fungi. }\end{array}$ \\
\hline 5 & $\begin{array}{l}\text { Spring } \\
\text { triticale }\end{array}$ & $\begin{array}{l}\text { Kissa }(\mathrm{k}-3721) \\
\text { (with medium } \\
\text { awn length) }\end{array}$ & Middle & Mexico & $\begin{array}{l}\text { Plants with medium awn length } \\
\text { were selected. Dense ear. High } \\
\text { quality grains. Resistant to lodg- } \\
\text { ing. Drought tolerant. Powdery } \\
\text { mildew resistant. } \\
\text { Dense ear with long awns. High }\end{array}$ \\
\hline 6 & & Ukro (k-3644) & Middle & $\begin{array}{l}\text { Russia, } \\
\text { Ukrain }\end{array}$ & $\begin{array}{l}\text { quality grains. Resistant to lodg- } \\
\text { ing. Drought tolerant. Powdery } \\
\text { mildew resistant. }\end{array}$ \\
\hline 7 & & Sears $57 \times$ Ukro & Late & $\begin{array}{l}\text { Russia, } \\
\text { Novosibirsk, } \\
\text { ICG }\end{array}$ & $\begin{array}{l}\text { Obtained from diallel crosses. } \\
\text { Low stem, Resistant to lodging. } \\
\text { Dense ear, awnless. Powdery } \\
\text { mildew resistant. }\end{array}$ \\
\hline
\end{tabular}

temperature, air humidity and soil moisture).

Yield is the total manifestation of the productivity and adaptability potentials of the studied genotypes. The potential yield was determined from the analysis of the productivity of the five best plants selected from each replication. The actual yield was determined based on the yield of the plot.

To assess the environmental adaptability of varieties, the following agrotechnical methods were used: 1) field trials in different soil conditions; 2) field trials in three different length of daylight. 
During the period of field trials there was quite a large variety of typical for Western Siberia weather conditions, particularly in seasonal distribution and sum of air temperature and precipitation from May to August. This allowed a thorough study the genotypes.

The analysis of long-term breeding data on early maturity, stress resistance and productivity was carried out using the following mathematical methods and software tools. Multivariate correlation analysis was used to assess the relationship between various traits of the studied samples [8]. The Ward's method of cluster analysis was used to compare the studied samples by a complex of traits and to select a group of plants that most closely matched the model of ideal variety [9]. The best samples were selected by evaluation of the plant breeding index, which was defined as the weighted sum of normalized productivity traits according to the formula [10]:

$$
Y=\sum_{k=1}^{K} q_{k} \cdot Y_{k},
$$

where $K$ is the number of traits; $q_{k}$ - expert weighting coefficients satisfying the condition

$$
\sum_{k=1}^{K} q_{k}=1 .
$$

Here $Y_{k}(k=1, \ldots, K)$ are normalized values of traits:

$$
Y_{k}=\frac{X_{k}-X_{\min (k)}}{X_{\max (k)}-X_{\min (k)}},
$$

where $X_{\max (k)}, X_{\min (k)}$ - the maximum and minimum values of the $k$-th trait.

The assessment of the genotype's stability was carried out by the value of the plant breeding index using the methods of Hangildin V.V. [11], Francis T.R. and Kannenberg L.W. [12], Eberhart S.A. and Russell W.A. [13], Nassar R. and Huehn M. [14]. The value of the standard deviation $\left(\sigma_{i}^{2}\right)$ and the coefficient of variation $\left(C v_{i}\right)$ and homeostaticity $(H)$ of the yield characterize the absolute and the relative variability of the productivity of the $i$-th cultivar. The regression coefficient $\left(\beta_{i}\right)$ measures the linear response of the $i$-th variety to varying environments. The variance of deviation from the regression $\left(s_{d i}^{2}\right)$ is a measure of the instability. Mathematical data processing was performed using the early self-developed computer program "Stability parameters of crops" [15].

\section{Results and discussion}

To obtain highly productive samples of spring triticale, the patterns of growth and development of plants in certain climatic conditions, as well as the effect of limiting factors on plants, were identified. Studies have shown that the sowing time has a significant impact on all traits. Based on long-term data, pairwise correlations of 10 traits were calculated: stem length, ear length, number of spikelets per ear, density of an ear, number of grains per ear, grains weight per ear, weight of 1000 grains, number of stems per plot, yield, number of days between germination and heading. Analysis of the correlation matrices allowed us to conclude that the traits "spike 
length", "number of grains per ear", "number of spikelets per ear", "grains weight per ear" and "number of days between germination and heading" form a correlation group for both wheat and for triticale. There was a high level of correlations between all pairs of traits in this group $\left(0.46<r_{i j}<0.91\right)$. The medium linear dependence was observed between the traits "weight of 1000 grain" and "ear density" in wheat $(r=0.31)$ and between the traits "weight of 1000 grains" and "stem length" in triticale $(r=0.5)$. The yield showed a high correlation with the trait "number of stems per plot" for both crops $(r=0.68 ; r=0.71)$. For a visual representation of the correlation groups, a cluster analysis was performed based on the correlation matrix of similarity. As a result, three clusters of traits were identified for wheat and triticale, but the set of traits was different (Figure 1).

Research data show that at different sowing times, the critical stages of plant development take place in different air and soil conditions. This changes the metamerism of the plant and the ear and affects the productivity of the plant, which is based on numerous correlations between traits. The lowest yield of all studied genotypes was observed for the third sowing date. The triticale lines Ukro and Kissa had the highest yield in the trial for the first two sowing dates $54.2 \mathrm{c} /$ ha and $54.5 \mathrm{c} /$ ha, respectively. They realized their productivity potential mainly due to the greater number of grains and grains weight from the ear (Figuer 2).

Summarizing the research results, we can conclude that the plant productivity was most influenced by the length of the ear, the number of grains in the ear, the number of spikelets in the ear, the weight of the grains of the ear, and the number of stems from the plot. To a lesser extent the yield associated with plant height and the weight of 1000 grains. It should also be noted that the variability of the vegetation conditions of plants in different years significantly influenced the yield. The difference between the average value of the yield for different sowing dates was: 2018 - for wheat $36.3 \mathrm{c} / \mathrm{ha}$, for triticale $76.7 \mathrm{c} / \mathrm{ha} ; 2019-31.4 \mathrm{c} / \mathrm{ha}$ and $48.4 \mathrm{c} / \mathrm{ha}$; $2020-46.0$ and $61.5 \mathrm{c} / \mathrm{ha}$, respectively. The maximum yield of the varieties, taking into account the sowing date, varied from year to year. It was found that under favorable conditions and correct cultivation techniques, the studied triticale samples are capable of surpassing wheat in yield (Figure 2).

The contrasting environmental conditions during the research period and the application of an integrated approach to the assessment of varieties based on the methods of the static and dynamic concept made it possible to evaluate the studied genotypes in terms of stability and adaptability.

a

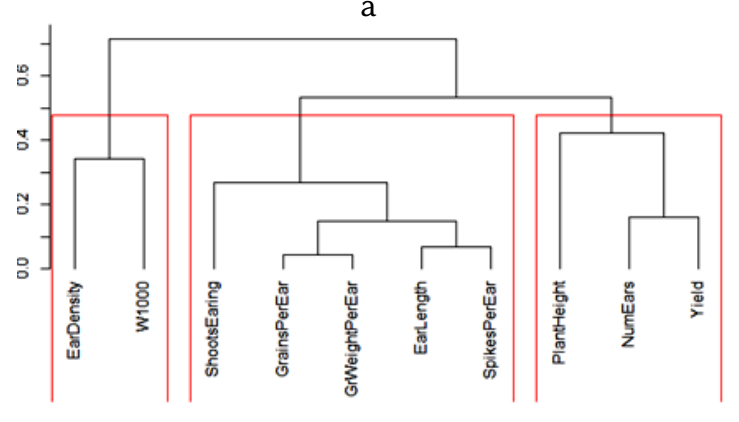

b

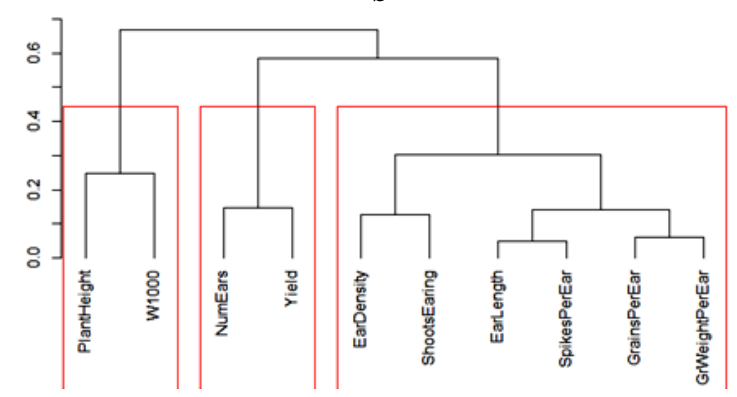

Figure 1: Dendrograms of quantitative traits: wheat (a) and triticale (b). 
The values of the coefficients of variation $(\mathrm{Cv})$ and homeostaticity $(H)$ characterized the triticale line Sears $57 \times$ Ukro as the most stable. The least stable wheat variety was Novosibirskaya 31 (Table 2).

The regression approach to the assessment of stability parameters in accordance with the method of Eberhart and Russell [13] showed that varieties Sibirskaya $12\left(b_{i}=0.97\right)$ and Ukro $\left(b_{i}=1.08\right)$, with regression coefficients closest to one, have a medium response to changes in environmental conditions. This means that a change in the productivity of a variety corresponds to a change in environmental conditions: in favorable environment it increases moderately, in unfavorable it decreases moderately.

Varieties Novosibirskaya 31 and Kissa, with a regression coefficient $b_{i}>1$, are more responsive to changes in growing conditions and require a higher level of agricultural technology. In unfavorable environments their productivity sharply decreases and there is a need to replace

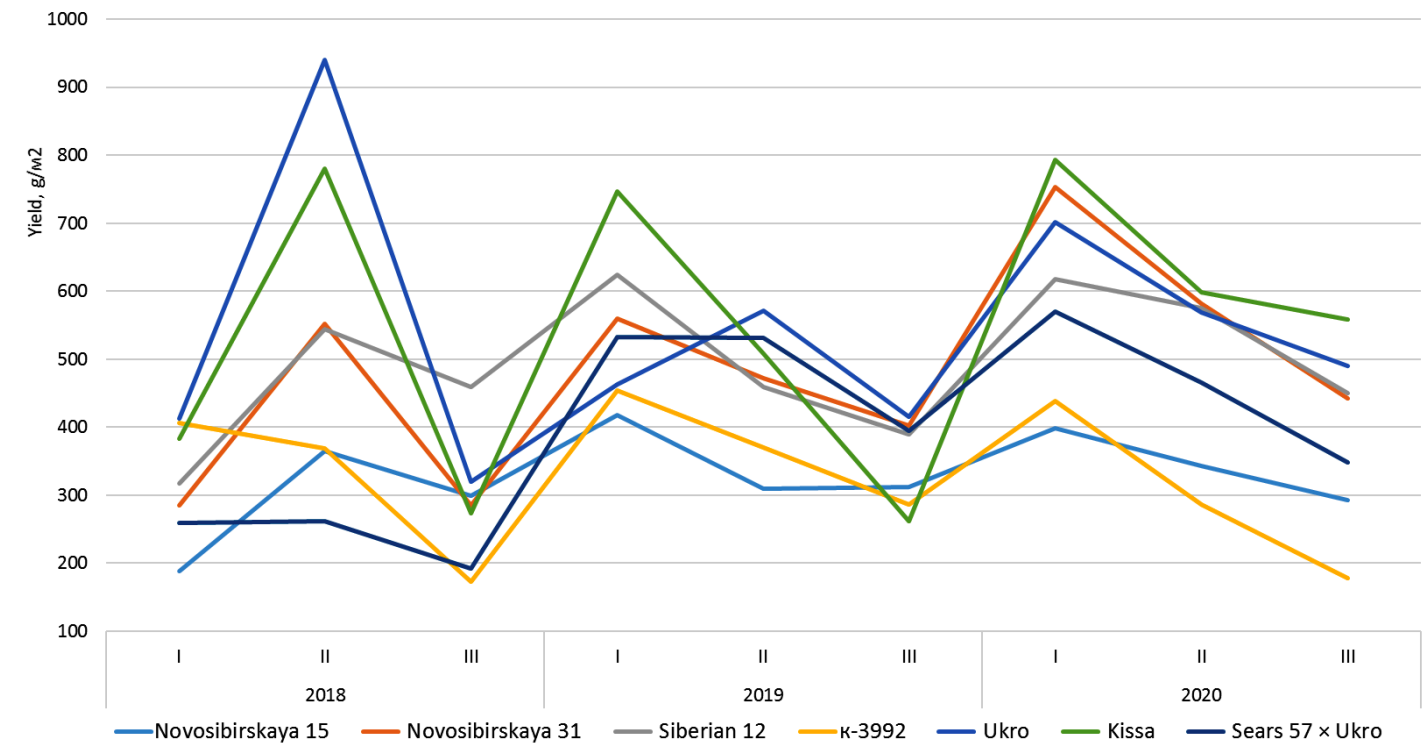

Figure 2: Actual grain yield of three spring wheat varieties and four spring triticale lines at three sowing dates in 2018-2020.

Table 2

Stability and adaptability parameters of the studied varieties.

\begin{tabular}{ccccccc}
\hline Variety & $\sigma^{2}$ & $C v$ & $H$ & $b_{i}$ & $s_{d i}^{2}$ & $S_{2}$ \\
\hline Novosibirskaya 15 & 0.05 & 20.97 & 8.86 & 0.68 & 0.0009 & 3.36 \\
Novosibirskaya 31 & 0.08 & 23.43 & 6.81 & 1.35 & 0.0004 & 3.61 \\
Sibirskaya 12 & 0.06 & 16.11 & 15.90 & 0.97 & 0.0012 & 3.50 \\
K-3992 & 0,06 & 16.65 & 13.96 & 0.48 & 0.0029 & 8.44 \\
Sears57× Ukro & 0.07 & 11.00 & 42.55 & 0.79 & 0.0002 & 1.61 \\
Ukro & 0.09 & 15.13 & 15.34 & 1.08 & 0.0034 & 4.44 \\
Kissa & 0.10 & 17.11 & 10.41 & 1.66 & 0.0010 & 6.36 \\
\hline
\end{tabular}


them with more adaptive varieties. Varieties Novosibirskaya 15, K-3992 and Sears57× Ukro with a regression coefficient $b_{i}<1$ can be recommended for cultivation in unfavorable environments. The lowest value of variance of deviation from the regression $\left(s_{d i}^{2}\right)$ characterizes variety Sears $57 \times$ Ukro as the most stable. The non-parametric parameter $S_{2}$ based on relative data rankings and proposed by Nassar and Huehn [14] gave a similar assessment of stability. In general, all studied varieties showed a high ability to develop under various environmental conditions.

Based on the evaluation of the plant breeding index (formulas (1), (2)), using data of long-term breeding trials and self-developed computer software, the following optimal valuable agronomic traits of hexaploid spring triticale (model of the ideal variety) were determined for the conditions of the West Siberian forest-steppe zone of the Ob region: plant height $-90 \mathrm{~cm}$; the number of spikelets per ear -25 pcs.; the number of grains of the main spike -65 pcs.; ear length 12-13 cm; grains weight per spike $-4 \mathrm{~g}$; weight of 1000 grains $-60 \mathrm{~g}$; the number of stems before harvesting -167 pcs.; yield $-69.3 \mathrm{c} / \mathrm{ha}$; germination-heading period -33 days; awnless or semi-awned forms are acceptable; drought resistance - high; resistance to major diseases (powdery mildew, brown and stem rusts, loose smut) - high; ecological plasticity is high.

The productivity potential of triticale significantly exceeds the potential of wheat, but it is not fully realized.

Varieties Ukro and Kissa according to the results of cluster analysis are identical to the model of the ideal variety. Figure 3 graphically presents the elements of the model of an environmental adaptive variety of spring triticale in comparison with the variety Ukro.

The analysis of the variability and correlations between valuable agronomic traits of genotypes indicates the possibility of purposeful breeding for adaptability to the conditions of the region when creating new high-yielding varieties of spring triticale.

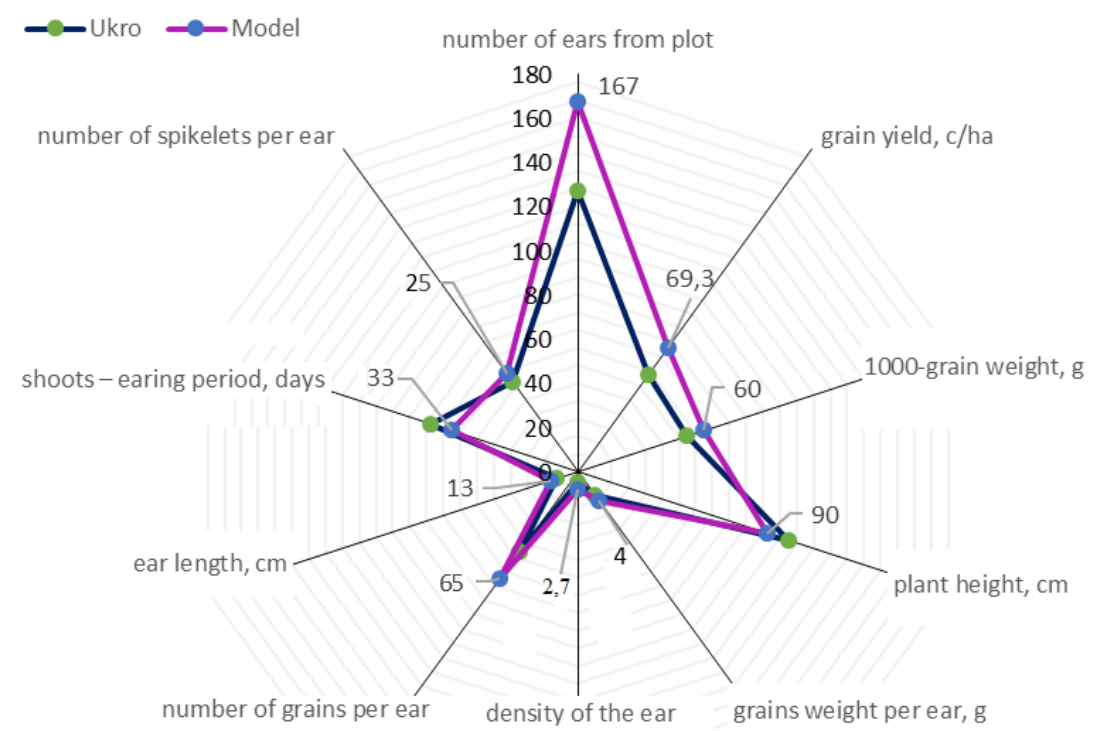

Figure 3: The elements of the biotype of forage spring triticale variety, environmental adaptive to the West Siberian forest-steppe zone of the Ob region. 


\section{Acknowledgments}

This work was supported by SFSCAT budget project No. 0778-2020-0001.

\section{References}

[1] Shamanin V.P., Truschenko A.Yu. General breeding and variety management of field crops. Omsk: Omsk SAU, 2007. 399 p.

[2] Koval S.F., Koval B.C., Chernakov V.M. What is the model of the variety: monograph. Omsk: OmSAU, 2005. 277 p.

[3] Winter and spring triticale in the Russian Federation: Collective monograph / A.M. Medvedev (Ed.). Moscow-Nemchinovka: MosNIISH "Nemchinovka", 2017. 284 p.

[4] Zhu F. Triticale: Nutritional composition and food uses // Food Chemistry. 2018. Vol. 241. P. 468-479.

[5] Feng Z., Qi Z., Du D. et al Characterization of a new hexaploid triticale 6D(6A) substitution line with increased grain weight and decreased spikelet number // The Crop Journal. 2019. Vol. 7(5). P. 598-607.

[6] Pinkal A.V. Creation and evaluation of primary winter triticale in the southern forest-steppe zone of Western Siberia. Dissertation abstract cand. agric. sc. Omsk, 2013. 19 p.

[7] Spring triticale Timur. State Register of Breeding Achievements. Available at: https://reestr. gossortrf.ru/sorts/8153738.

[8] Efimov V.M., Kovaleva V.Yu. Multivariate analysis of biological data. St. Petersburg: VIZR RASXN, 2008. $87 \mathrm{p}$.

[9] Fraley C., Raftery A. Model-based clustering, discriminant analysis, and density estimation // Journal of the American Statistical Association. 2011. Vol. 97. P. 611-631.

[10] Grebennikova I.G., Cheshkova A.F., Chanyshev D.I., Stepochkin P.I. The use of computer software in applied problems of artificial selection // Proceedings of the All-Russian Conference "Spatial Data Processing for Monitoring of Natural and Anthropogenic Processes", 2019. P. 68-73.

[11] Hangildin V.V., Shayakhmetov I.F., Mardamshin A.G. Homeostasis of crop components and prerequisites for creating a model of spring wheat variety // Genetic Analysis of Quantitative Traits of Plants. Ufa, 1979. P. 5-39.

[12] Francis T.R., Kannenberg L.W. Yield stability studies in short-season maize. I. A descriptive method for grouping genotypes // Can. J. Plant Sci. 1978. Vol. 58. P. 1029-1034.

[13] Eberhart S.A., Russell W.A. Stability parameters for comparing varieties // Crop Sci. 1966. Vol. 6(1). P. 36-40.

[14] Nassar R., Huhn M. Studies on estimation of phenotypic stability: Tests of significance for nonparametric measures of phenotypic stability // Biometrics. 1987. Vol. 43. No. 1. P. 45-53.

[15] Cheshkova A.F., Stepochkin P.I., Aleynikov A.F., Grebennikova I.G., Ponomarenko V.I. A comparison of statistical methods for assessing winter wheat grain yield stability // Vavilov Journal of Genetics and Breeding. 2020. Vol. 24(3). P. 267-275. 